\title{
自動分割分包機による散剤・顆粒剤混合物の分割後の均一性の検討*1
}

\author{
島川治巳，小野 彪，薹内徳蔵，坪田 芳，林 幸男 \\ 滋賀医科大学医学部附属病院薬剛部*2
}

\section{Uniformity of Powder-Granule Mixture after Divided by Automatic Dividing and Packing Machine*1}

\author{
HARUMi SHIMAKaWA, TAKESHI ONO, TOKUZO Minouchi, \\ KAORU TSUBOTA, and YUKIO HAYASHI \\ Hospital Pharmacy, Shiga University of Medical Science*2
}

(Received July 20, 1981)

\begin{abstract}
Components of a powder-granule mixture are liable to be separated by vibration. For this reason, in order to evaluate a practicability of the machine (L-2) equipped with a linear vibrating feeder, comparative examinations were made on the uniformity of the mixtures after the division by each of 3 machines ( $L-2, B$ and $R$ ). The machines used were the same as that which had been used in the previous work. The samples used were the powder-granule mixtures in 8 grades of mixture ratio (powder/granule) ranging from $1 / 15$ to $15 / 1$, and powder and granule were prepared in our pharmacy. $10 \mathrm{~g}$ of the sample was divided into 15 parts by each of these machines, and dividing was repeated 5 times.

As for variation of percent powder content after the division, the difference between the machine L-2 and B was not significant. However, as for mixture wcight and powder weight after division, the machine $\mathrm{L}-2$ showed smaller variations than the machine $\mathrm{B}$. When the machine $\mathrm{L}-2$ is used, the mixture shows a separation tendency because of vibration, which is one of two main functions of the feeder. However, each of the components is considered to be divided accurately by alternating motion, which is the other function of the feeder. The machine $R$ caused larger variations of mixture weight, powder weight and percent powder content after the division than any other machine tested.
\end{abstract}

Keywords_-automatic dividing and packing machine; powder-granule mixture; mixture ratio; weight variation; content uniformity; dividing; dispensing; linear vibrating feeder

\section{緒言}

製剂技術の進歩により各種の造粒が可能となり，調剂 や服用に便利で，かつ有用な調剂用の造粒剤が増加して いる. その結果, 処方には散剂と造粒剂の組み合わせ例 が多くみられる．配合される医薬品の粒子径差が大きい 場合, 特に血中薬物濃度や安全域を問題にする薬物が配

*1 本報を「粉粒体の機器分割に関する研究」第 2 報と する．日本薬学会第 100 年会（東京，1980年 4 月） で発表.

*2. 大津市瀬田月輪町 ; Tsukinowa-cho, Seta, Otsu-shi, 520-21 Japan
合されている場合には, 分割後においても精度の高い成 分の均一性が必要である. 今日多数の自動分割分包機が 普及したが，これらの自動機器は操作性のみならず, 分 割後の混合成分の均一性をある一定限度以上に保証する ものであることが望ましい.

著者らは, 直進振動フィーダーを供給機に応用した自 動分割分包機を使用するに際し，その機構上の特徵であ る振動が混合された散剤と顆粒剂を分離させることが知 られている1) ため, 本機種と従来用いられてきた機種と を比較して, 分割後の散剂・顆粒剂混合成分の均一性に ついて検討した. 


\section{実踰 の 部}

\section{1. 実験材料}

1) 試 料

a ) 散剤：日本薬局方乳糖に定量用着色版としてカル バゾクロムスルフォン酸ナトリウムを一定重量比率で加 えて混合後, 日本精機社製遠心粉砕機により 100 メッシ こで 2 回粉砕し，これを散剤として実験に用いた.

b ) 顆粒剤：ヒドロキシプロピルセルローズ（以下 HPC と略す）の含有量が $3 \%$ となように日本薬局方 乳糖に HPC-エタノール溶液を加え, 練合後, 20 メッシ ュのふるいにて押し出し造粒した. 乾燥後12〜32メッシ ュの部分をとり，これを顆粒剂として実験に用いた.

2）分割分包機

前報 ${ }^{2)}$ と同様に，供給機として直進振動フィーダーを 有する小西製作所製 $\mathrm{KC}-787-\mathrm{K} 15$ 改良型（以下 $\mathrm{L}-2$ 型 と略す), ベルトコンベアーを有する小西製作所製 $\mathrm{KC}$ 747-K 12 型 (以下 B 型と略す), および V型受器を有す る東京商会製 TOWA VS-42 型（以下R型と略す）を 分割分包機として実験に用いた.

\section{2. 実硂方法}

1）試料の物性測定

試料の物性測定は, 小西製作所製安息角測定器 $\mathrm{FK}$ 型, みかけ密度測定器, みかけ比容積減少度測定器 RHK 型, 逃飛率測定器 HK 型, および藏垣医理科工業製粒度試験 器を用いて行った。

2）分割分包方法

散剤および顆粒剂計 $10 \mathrm{~g}$ を科取し，小西製作所製混 合機 KC-SW 型で 8 秒間混合後, 自動分割分包機を用い て15分割分包した．科取重量比は分子を散剤，分母を顆 粒剂とする分数で表示し，これを配合比とした，L-2 型 と B 型の場合は一回の15分割に要する時間が約 38 秒の一
定となるように条件を設定し， R 型の場合はへラを用い て手動で慎重にならし操作を行った．また，いずれも第 1 包目から第15包目まで分割分包の順番に番号をつけ， これを分包番号とした. 分割分包は各群 5 回繰り返して 行い，その前後に風袋のみを15包ずつ計30包作製した:

3）混合成分の均一性の測定

分割分包された各 1 包の風袋込みの重量をメトラ一值 示天科 H 54 AR により精科し, 別に求めた風袋重量と の差を求めて，これを分割混合物重量とした，風袋重量 は各群の実験毎に作製した 30 包の風袋の平均重量として 求めた. 各 1 包中の散剤重量は, 散剤中に一定重量比率 で添加されたカルバゾクロムスルフォン酸ナトリウムを 定量することにより求め，これを分割散重量としたす なわち, 各 1 包中の散・顆粒混合物の全量を水に溶解し て一定容量とした後, 島津分光光度計 $210 \mathrm{~A}$ を用いて カルバゾクロムスルフォツ酸ナトリウムの極大吸収波長 $364 \mathrm{~nm}$ で吸光度を測定し，別に作成した検量線より散 剂重量を求めた。なお， $364 \mathrm{~nm}$ における吸光度に対す る HPC および乳糖の影響はみられなかった。 各 1 包中 の顆粒重量は分割混合物重量と分割散重量との差として 求め, これを分割顆粒重量とした. 分割散重量の分割混 合物重量に対する比率（\%）を求め，これを分割散含有 率とした。

\section{実験結荲および考察}

\section{1. 試料の物性}

実験に用いた散剂および顆粒剂の物性を Table 1 に 示した. 散剤については，みかけ比容積減少度が約 50 $\%$ ，逃飛率が小さく凝集性が大で，軽くてかさ高いこと が認められた．顆粒剤については，みかけ比容積減少度 が $9 \%$ ，逃飛率が $42 \%$ で，一般的な顆粒剂の物性を示し， また比較的表面に凹凸があり軽いものであった。

Table 1. Physical Properties of Samples

\begin{tabular}{l|cc}
\hline \multicolumn{1}{c|}{ Sample } & Powder & Granule \\
Physical property & & \\
\hline Angle of repose $(\circ)$ & $54 \pm 2$ & $46 \pm 1$ \\
Apparent density $\left(\mathrm{g} / \mathrm{cm}^{3}\right)$ & $0.36 \pm 0.01$ & $0.43 \pm 0.00$ \\
Relative reduction of volume & $0.48 \pm 0.01$ & $0.09 \pm 0.01$ \\
Escapability $\quad(\%)$ & $6.0 \pm 1.3$ & $42.4 \pm 1.1$ \\
Particle size distribution & $100 \mathrm{mesh}$ & $12-32 \mathrm{mesh}$ \\
\hline
\end{tabular}

\footnotetext{
* Tapping speed is 100 times/min.
} 


\section{2. 各機種による分割後の混合成分の均一性の比較}

配合比 $1 / 3$ の散・顆粒混合物を分割分包した場合につ いて, 第 1 包目から第15包目までの分包番号と分割散含 有率との関係を機種別に求めて, その結果を Fig. 1 に 示した. また15分割分包により得られた15包について, 分割混合物重量, 分割散重量および分割散含有率の変動 係数 (以下 C. V. と略す) を前報 ${ }^{2}$ と同様にして求めた 後, 機種と C. V. の関係を Fig. 2 に示した. Fig. 1 よ り， B 型および L-2 型の場合は，分包番号間における 分割散含有率の変動が R 型よりも小さくてほぼ一定であ り, 分包番号内のバラッキ,すなわち各分包番号に批け る標準偏差も小さいことが認められた. Fig. 2 には各群 5 回繰り返しにより得られた各 5 個の C.V.をプロット し，その 5 個の C.V. の平均值を棒グラフで示した. 平 均 C.V.を機種間で比較すると, 分割混合物重量, 分割 散重量および分割散含有率のいずれも $\mathrm{R}$ 型は他 2 機種よ ク大きい C. V. を示し，それらは高度に有意 $(p<0.01)$ であった.

L-2 型と B 型との比較においては，L-2 型の方が分割 混合物重量は高度 $(\mathrm{p}<0.01)$ に, 分割散重量は有意 $(\mathrm{p}$ <0.05）に C. V. が小さく，分割散含有率の C. V. には 有意差は認められなかった. L-2 型は, その機構上の特 徵である振動のためにフィーダー板上で散・顆粒混合物
が両成分に分離し，それが原因となって各 1 包中の分割 散含有率のバラッキが大きくなるのであろらと予想され た. しかし L-2 型と B 型との間で分割散含有率の C. V. に有意差がなかったことから, 直進振動フィーダー板上 で散・顆粒混合物の分離がある程度生じです, 供給機が 各分割ホール上で往復運動するために, その現象は打ち 消されていると考えられる. また，L-2 型と B 型との間 で，分割散含有率の C. V. には有意差はないが，分割混 合物重量と 分割散重量の C. V. には有意差が認められ た.これは両機種間の供給機の定量的供給能に差がある ことによると考えられる.

\section{3. 各程配合比による混合成分の均一性の比較}

前記 2 の結果により， L-2 型は他 2 機種に比較して良 好な 分割性能を有することが認められた. そこでこの L-2 型を用いて，散郕と顆粒剂の配合比を種々変えて実 験を行い，混合の均一性に与える配合比の影響を検討し た. Fig. 3 には 8 段階の配合比における分割散含有率と 分包番号との関係を示した. 分包番号間のバラッキおよ び分包番号内のバラッキは，いずれの配合比においても 小さいことが認められた.

15分割分包により得られた15包間のバラッキをさらに 詳しく検討するために, 分割散含有率の 標準偏差 (以 下 S. D. と略す）および C.V. と各種配合比との関係を

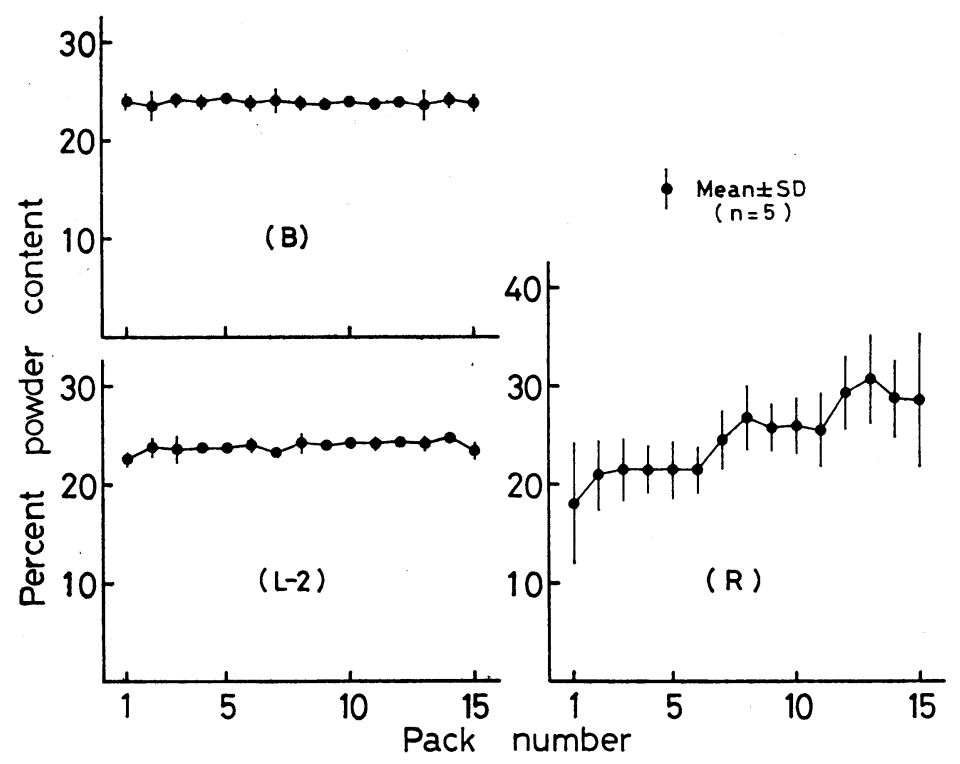

Fig. 1. Relationship between Pack Number* and Powder Content after Division

*15 packs are numbered in the order of dividing and packing.

Mixture ratio: Powder $/$ Granule $=1 / 3$ 


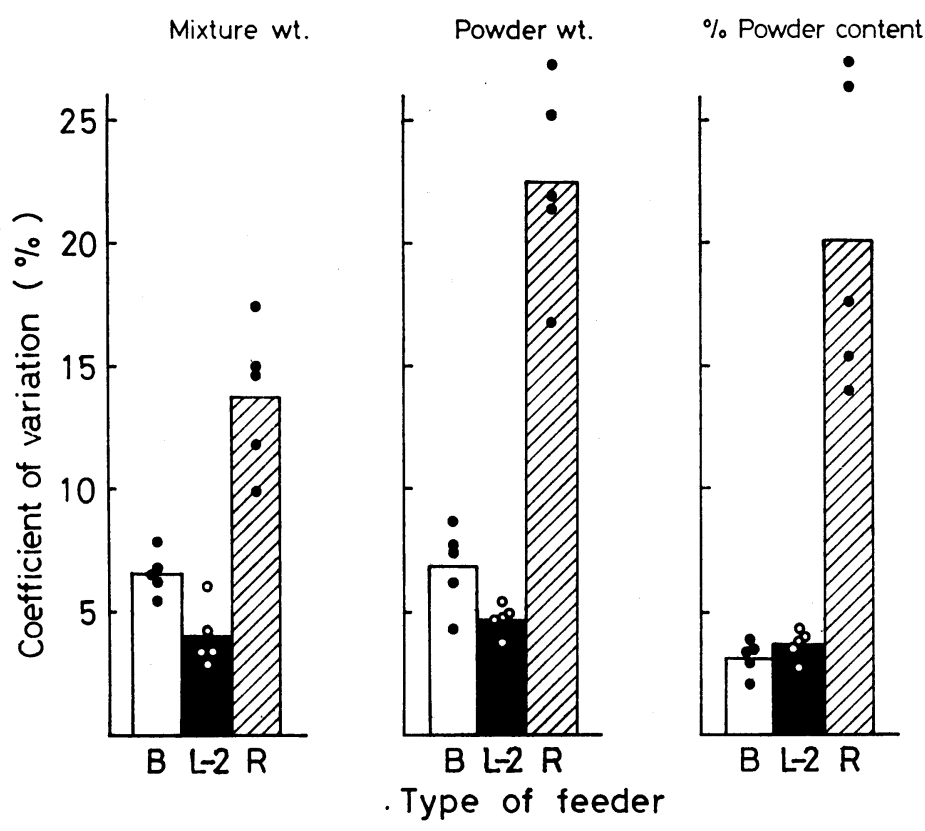

Fig. 2. Comparison of 3 Types of Machines on Coefficients of Variation of Mixture Weight, Powder Weight and Percent Powder Content after Division Mixture ratio: Powder $/$ Granule $=1 / 3$

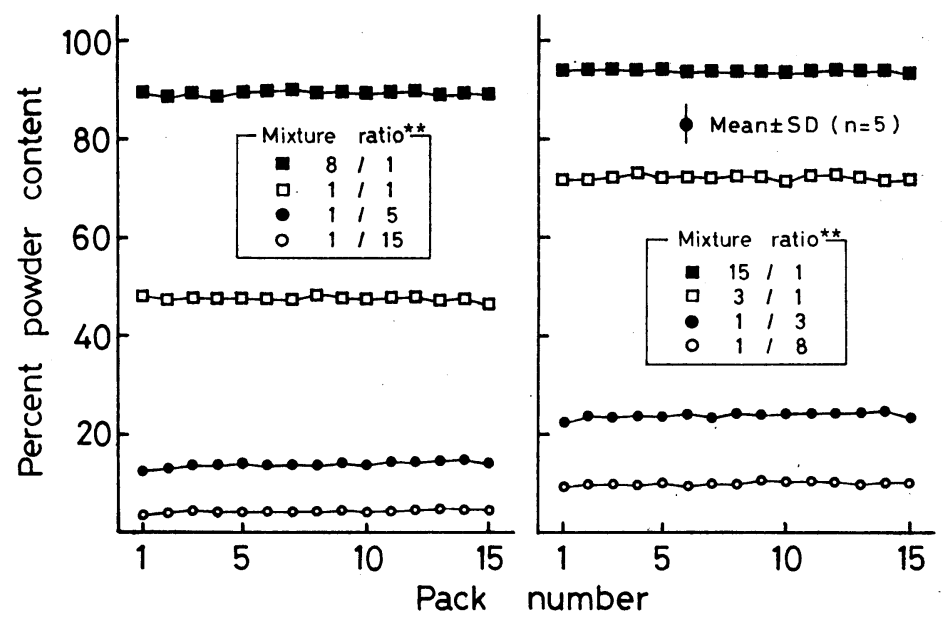

Fig. 3. Relationship between Pack Number* and Powder Content after Division

*15 packs are numbered in the order of dividing and packing.

Type of feeder: L-2, ** : Powder/Granule

Fig. 4 に示し, さらに分割散重量および分割顆粒重量の C. V. と各種配合比との関係を Fig. 5 に示した. いずれ も各群 5 回繰り返しによる各 5 個の S. D. または C.V.
を丸印で示し，その 5 個の S. D. または C.V. の平均値 を棒グラフで示した. Fig. 4 より，分割散含有率のS.D. は散剤の配合比率が大きくなるにつれて增大する傾向が 


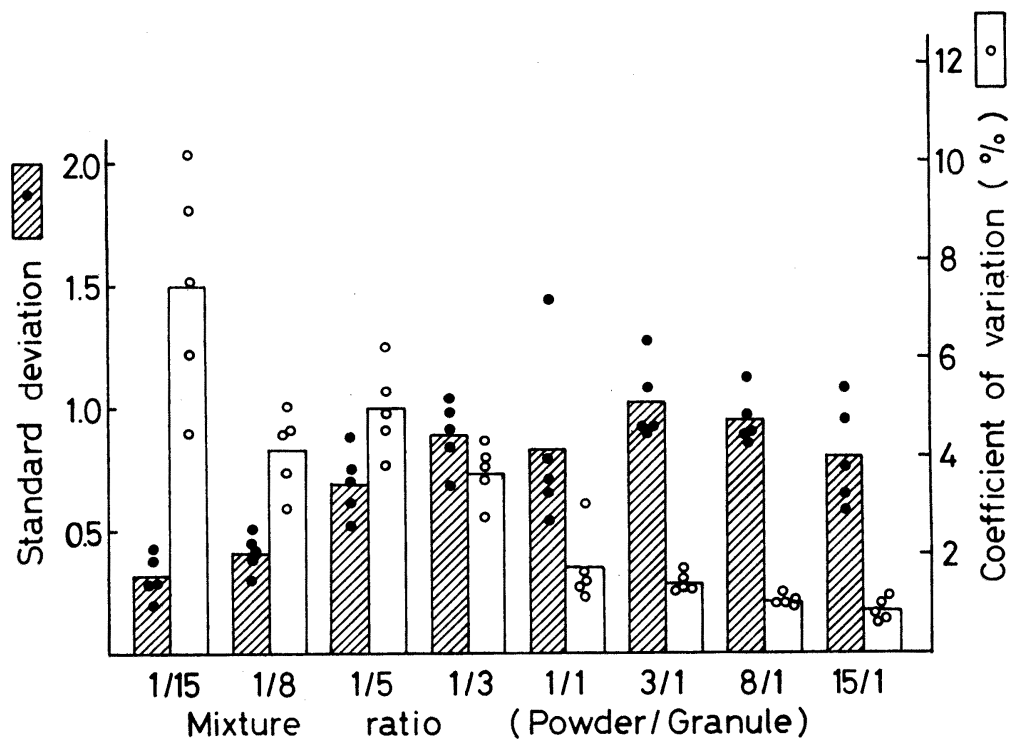

Fig. 4. Effect of Mixture Ratio on Standard Deviation and Coefficient of Variation of Percent Powder Content after Division Type of feeder : L-2

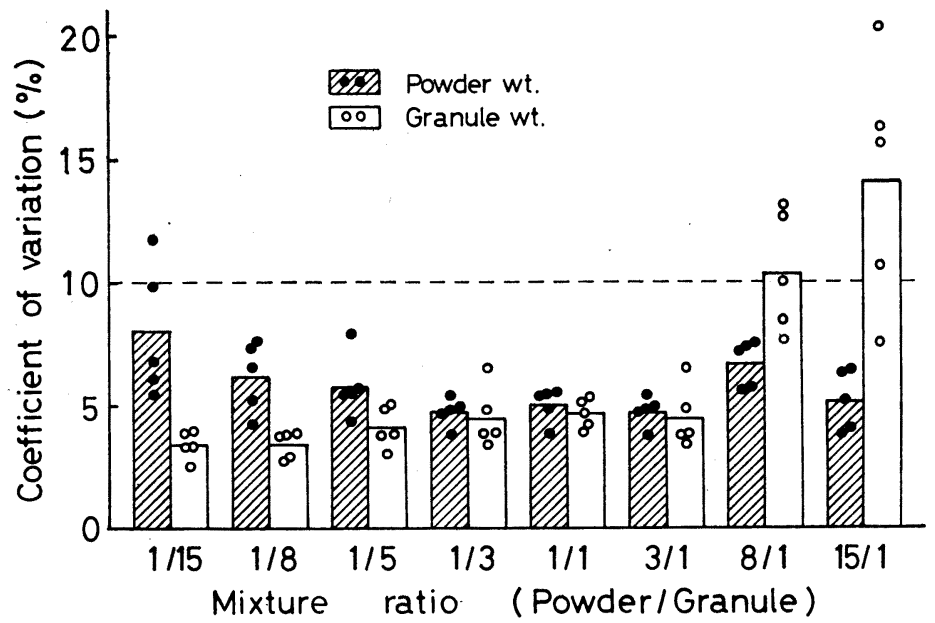

Fig. 5. Effect of Mixture Ratio on Coefficients of Variation of Powder Weight and Granule Weight after Division Type of feeder : L-2

認められたが, 配合比 $1 / 3$ 以上においてはほぼ同程度で あった. 一方, C. V. は散剤の配合比率が大きくなるに つれて減少する傾向がみられた. Fig. 5 より, 分割散重 量は配合比 $1 / 15$ における 1 例を除いてすべて10\%以下の C. V. であることが認められ，散剤の分割重量の均一性 は，極端に散昘の配合比率が小さい場合を除き良好であ
ると考えられる. 分割顆粒重量の C. V.は，顆粒剤の配 合比率が大きくなるにつれて減少する傾向が認められ， 特に配合比 $3 / 1$ 以上で顆粒剤が配合される場合は，C.V. はすべて $10 \%$ 以下で平均 C.V.は $5 \%$ 以下となり, 特に 問題はみられなかった．また，配合比 $1 / 3 \sim 3 / 1$ におい ては分割散重量と分割顆粒重量の C.V. がほぼ等しくな 
り，この範四外では配合量の小さい方の成分の C.V.が 上り大きくなることが浔められた。

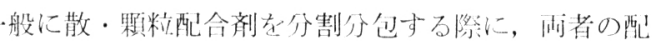
合量に大きな差がある場合は，配合量の小さい万の成分 の分割重量の C.V. が大きくなるため問題となることが 多い，をこで配合比 $1 / 15$ 亿批名分割散重量の C.V.と

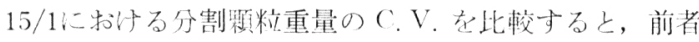
の方が小さいことが浔められ，唒合比 $1 / 8$ と $8 / 1$ の場合 こおいても同様であった。 寸なわち，多量の顆粒剤に少 量の散成を配合した場合の分割散重量のC.V.の方が，そ の逆の場合の分割顆粒重量の C.V.よりも小さくなるこ とが認められた。これは散剤の配合量が顆粒剂に比べて 非常に少ない場合には，顆粒剂の表面に散剤が付着する 現象が生じて，その状態で分割されることが考えられ， これが分割散重量の C.V. 在小さくする原因であろうと 考兄られる。この顆粒剤に散剂が付着する現象とその效 果等については，さらに詳紐な検討が必要であるととも
に，散剤子顆粒剂が 同時に 処方されている時に調剂指 針 ${ }^{3)}$ の推桨する各々別々に分割するいわ和る。度まき法 为，機械分割に適用するにあたって再検討与る必要があ ると考觉られる。

今回実験に用いた散剤および顆粒剤は，物性の異なる 多数の製剤を完全に代表するものではないため，種々の 物性を有与る試料を用いた検討为必要であるらと思われ るが，以上の実験結果から，往復運動機能のある直進振 動フィーダーを供給機とした自動分割分包機は，散・顆 粒配合剂についても十分使用可能であると考える.

\section{文献}

1）七條伊作, 谷古宇秀, 杉原正泰：病院薬学, 6, 59 (1980).

2）島川治巳, 小野彪, 坪田芳, 致内德蔵, 中西 真基子, 林 幸男: 病院薬学, 8, 138 (1982).

3) 日本薬剂師会編：第六改訂調剂指針, 薬事日報社, 東京, 1977 , pp. 64 65.
劇 胆汁分泌促進剤

\section{スIJコLし}

アネトールトリチオン $12.5 \mathrm{mg} /$ 錠 含有

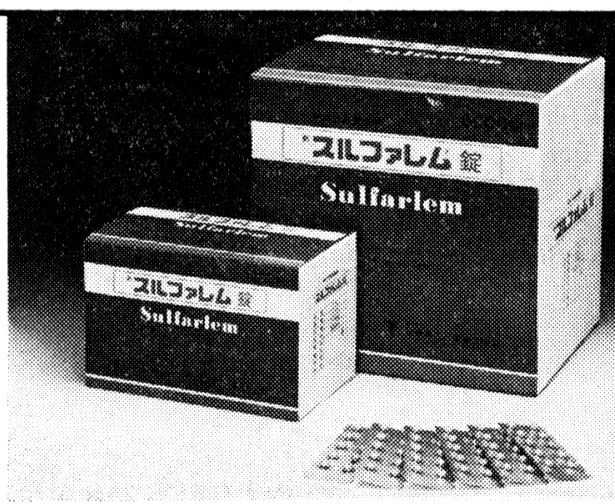

包装

1,200 錠 6,000 錠

(PTP) 10 鋜 $\times 12010$ 鋔 $\times 600$

〉间・成分製刘にスルファレム丸( $12.5 \mathrm{mg} /$ 丸)があります

規制区分：劇 薬

薬価基準収載品

\section{製造東菱薬品工業株式会社} 東京都千代田区有楽町1-10-1

提携 ラ テ マ 社(フランス)

保谁素排泄能促進/瓜素合成能

薬理作用の詳䋖及び使用に:の注意については製品 添付文苦老ご參照卜さい。

\section{販売元}

找桑莧昆工業株式会社 